\title{
街路におけるべンチの向きが着座者の行為に与える影響 EFFECTS OF THE DIRECTIONS OF BENCHES ON THE BEHAVIOR OF SEATED PEOPLE IN A STREET
}

\author{
小林茂雄*, 勝又 亮** \\ Shigeo KOBAYASHI and Ryo KATSUMATA
}

\begin{abstract}
The purpose of this research is to examine the relation between the direction of benches and sitting behaviors in a street. An observational investigation that targeted public users, and an evaluational experiment by subject were conducted, and the following aspects became clear.

1. The number of people who sat on benches was larger when the benches were arranged face to face than when they were arranged back to back. This was especially remarkable in users for a short time. The reason was assumed to be related to accessibility from the street to the benches.

2. The number of men who sat on benches was larger when the benches were arranged back to back. On the other hand, the number of women who sat on benches was larger when the benches were arranged face to face.

3. Behaviors such as eating and drinking were observed more frequently when benches were arranged face to face. Subjects reported that they felt that people sitting on benches back to back were annoyed by pedestrians.
\end{abstract}

Keywords: sitting behavior, direction of bench, street, eating and drinking, affordance, observational experiment 着座行為、ベンチの向き、街路、飲食行為、アフォーダンス、観察実験

\section{1. 研究の背量と目的}

商業店舗が並ぶ歩行者中心の街路空間では、歩行する行為だけ でなく、喫煙や飲食、待ち合わせなどといった様々な種類の行為がな される。そうした行為の全てが好ましいものであるとは限らないが、 人々が滞留し、活動することは、街路空間の活性化にもつながるこ とが多い。しかし実際には、ベンチが配置されるなど滞在行動を促 す装置やスペースが設けられている事例はまだ少数である。本研究 では、街路において既にベンチが設置されている着座空間に着目 し、その配置の違いによる利用者の行為や滞在時間等を調査し、行 為をしやすくする要因を明らかにすることを目的としている。それによ り、特定の行為を促したり防いだりするような、街路空間のデザイン の指針に寄与することを目指している。

着座行為に関する心理的研究は、古くはSommer ${ }^{1)}$ 名、着座位置 や方向によって会話のしやすさの心理的状況が異なることを示してい る。国内では小松ら ${ }^{2)}$ が、病院の待合室を対象として椅子の配置に よる効果を検討している。屋外空間を対象としたものとして、大島ら 4)は、高齢者が外出する際の座りスペースの塞態や意識を調査し、 着座できる場所を整備することの重要性を示している。吉田ら゙5 は駅 に近接した屋外空間において線状に着座する人々の位置を調査し、 求められる対人距離について分析している。堀口ら ${ }^{6)}$ は街路におけ
る着座者の観察調査とアンケート調査から、選択されやすい着座環 境と着座装置の特徵を示している。ただしこれらの研究では、着座 しながらなされる行為の内容まで踏み込んでいるわけではない。屋 外空間でのベンチに座る向きと行為の関係を研究したものとして、池 のある公園のベンチの使われ方を調查した森ら7)のものがある。調 査の結果、池向き方向に着座するときには、飲食・新聞・煙草など の個人行為が多く、池と反対向きに着座するときには、電話やメー ルなどコミュニケーションをとる行為が多いなど、座る向きによって発 生する行為内容が異なることを示した。周辺環境に対するベンチの向 きとそこでの行為を対象としている点で、本研究と一致している。本 研究の既往研究と異なる特徵としては、街路に置かれたベンチを対象 とすることと、ベンチの配置と行為との関係を扱うこと、昼間から夜間 にかけての利用状況を調查すること、着座者周辺の他者の影響を把 握しようとすることにある。

\section{2. ベンチの向きによる利用行動の観察調査 \\ 2.1 調查対象}

本研究では研究対象として、東急電鉄・自由が丘駅の南側に位置 する九品仏川緑道に置かれたベンチを選定した。この街路は九品仏 川を暗渠化してできたものであり、中央の緑道部分に植栽やベンチ、
* 武蔵工業大学工学部建築学科 准教授·博士 (工学)

** 武蔵工業大学大学院工学研究科建築学専攻 大学院生
Assoc. Prof., Dept. of Architecture, Musashi Institute of Technology, Dr. Eng. Graduate Student, Dept. of Architecture, Musashi Institute of Technology 
灰血が配置されている。図 1 に対象とした範囲を示す。駅の改札口 から約 $80 \mathrm{~m}$ と至近距離にあり、店舗前の動線と休憩スペースとが区 別され、また車の通行が少ないため、休日・平日ともに昼間から夜 間まで利用者は多い。街路の歩行者は夜間に少なくなるものの、24 時頃まで途絶えることはない。ベンチは互いに向かい合う状態で配 置されており、両側の街路に背を向けていることになる。

\section{2 事前調查}

図1の円内のベンチと街路において、事前調査を行なった。2005 年 9 月上旬の平日の 2 日間、午後 13 時から 24 時まで、 1 時間置 きに 30 分間ほど断続的に観察を行った。図 2 のベンチを対象とし て、2日ともに約 150 名程度の利用行動を観察した。このときのベン チは、互いに内向きに並べられている。

調査の結果、利用者は昼間に非常に多くみられ、夕方以降徐々 に減っていくことが分かった。周辺の店舗は、20時に閉店するもの が多く、閉店後は利用者が少なくなった。ただし、23時過ぎまで少 数であるが利用されていた。昼 間は、観察をしたベンチのほとん どが利用されている状態であり、 人の入れ替わりも頻繁であった。 また、隣り合ったベンチに座って 会話をすることはあっても、向き 合った状態で会話を交わす利用 者は見受けられなかった。

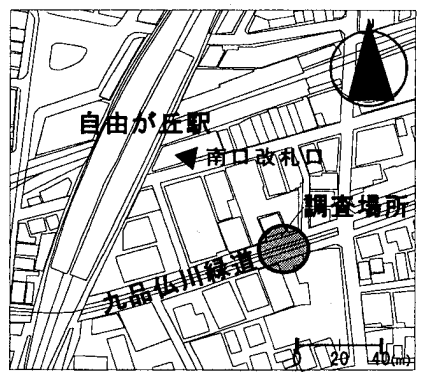

図 1 九品仏川緑道地図

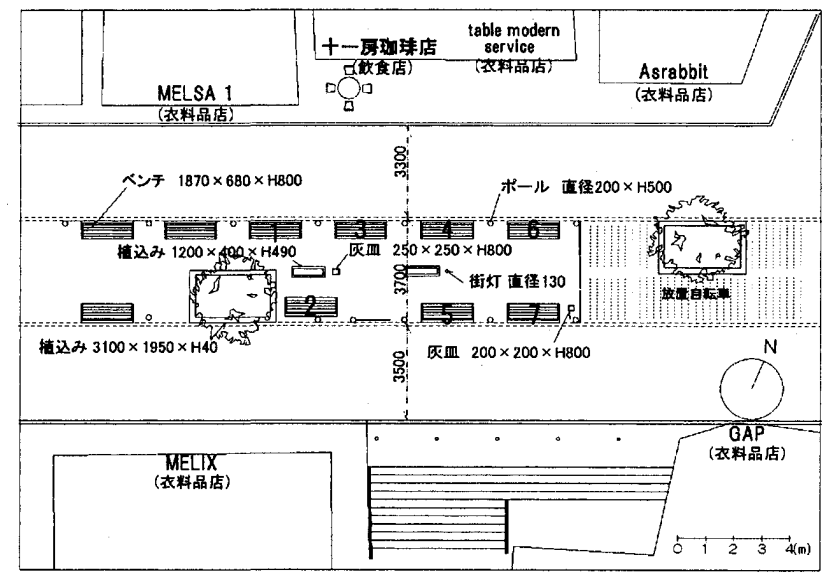

図 2 調查場所平面図

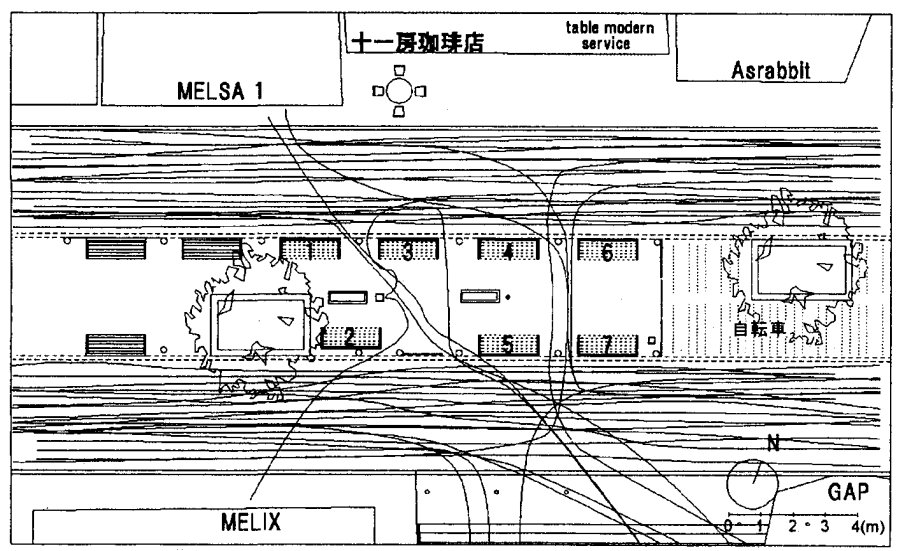

図 4 歩行者軌跡(左:内向き右:外向き)
利用者には様々な行為がみられた。携帯電話を操作したり、喫煙 をするなどといった、短時間の休䕀のためだけの利用が多かったが、 中には、食事をしたり、寝ころんだりと長居する人もいた。そうしたく つろいだ行為や、プライベートな行為は、歩行スペースに背を向け たベンチの配置によって生じやすいのではないかと思われた。歩行 者からの視線の注ぎ方を変えることで、特定の行為をやりやすくした り、制限したりするのではないかと考えられた。

\section{3 調查概要}

街路に対するべンチの向きによって、利用状況にどの様な差異が 生じるかをみるため、利用者の行動を観察する調査を行なった。図 2 のベンチ 7 脚（No.1〜 7) を、前後で向き合った状態（以後、内 向きと表記）と、背を向けた状態（以後、外向きと表記）の 2 種類 に変えるものである。それぞれの条件で、2005 年 9 月〜 11 月の 平日 3 日間、休日 1 日、 $13: 30 \sim 15: 30 、 17: 00 \sim 19: 00$ 、 $20: 00 \sim 22: 00$ (以後、順に昼間、夕方、夜間と表記) の 3 つの 時間帯に分けて、利用者の行動を観察した注1)。調査日は全て晴天 であった。図20ベンチ周辺の店舗は、20 時に閉店するが、内部 の照明は 22 時まで点灯している。調査項目は、ベンチを利用する 者の属性、利用人数、滞在時間、行為の種類である。調査者は2 名であり、対象外のベンチや植込み、階段などに別々に座って、目 視により観察した。

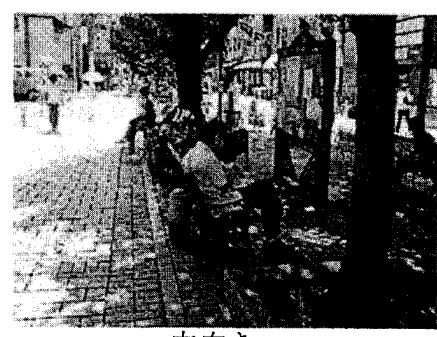

内向き

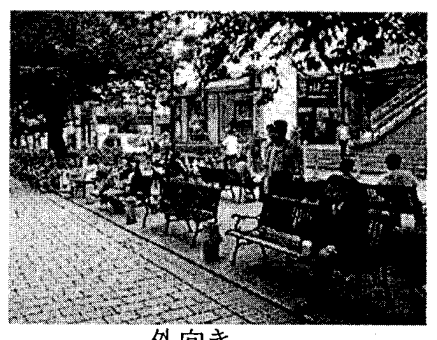

外向き
図 3 調查時の風景

表 1 調查日と利用状況

\begin{tabular}{|c|c|c|c|c|c|c|c|c|c|c|}
\hline & & & & & & & & 利用 & 数(人) & \\
\hline & 調查日 & 天気 & $\begin{array}{c}2 \\
\left({ }^{\circ} \mathrm{C}\right)\end{array}$ & $\begin{array}{l}\left.{ }^{\circ} \mathrm{C}\right) \\
0\end{array}$ & 湿度(\%) & 日没時刻 & 冝13:30- & 817:00- & 夜 20:00- & 合言 \\
\hline & 10.25 (火) & 睛れ & 24 & 14 & 28 & $16: 54$ & 101 & 68 & 31 & 200 \\
\hline 内自き & \begin{tabular}{|l|}
0.28 (金) \\
\end{tabular} & 铺れ & 21 & 13 & 56 & $16: 50$ & 110 & 74 & 35 & 219 \\
\hline & 11.08 (火) & 晴れ & 22 & 12 & 29 & $16: 40$ & 92 & 88 & 32 & 212 \\
\hline & 10.30 (日) & 䀯れ & 19 & 17 & 56 & $16: 48$ & $\frac{\pi}{119}$ & 116 & 25 & 260 \\
\hline & 9.26 (月) & 晴れ & 25 & 19 & 54 & $17: 33$ & 80 & 94 & 37 & 211 \\
\hline 外向声 & 9.27 (火) & 睛れ & 22 & 18 & 56 & $17: 31$ & 98 & 74 & 42 & 214 \\
\hline & 9.30 (金) & 睛れ & 24 & 17 & 49 & $17: 27$ & 81 & 88 & 52 & 221 \\
\hline & $10.02(日)$ & 瑱れ & 31 & 20 & 56 & $17: 24$ & 162 & 121 & 65 & 348 \\
\hline
\end{tabular}

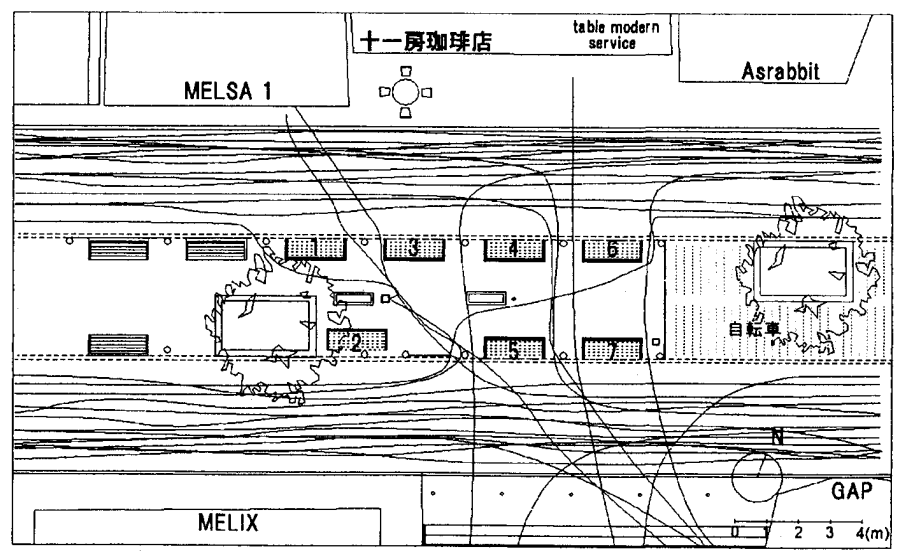




\section{4 調査結果と考察}

\section{1) ベンチの利用状況}

各々のベンチの向きのとき、隣接する街路における歩行者の位置 を観察した。図4は、平日の昼間 10 分間の歩行軌跡を示したもの である。両条件とも、北側と南側の両方のベンチが利用されていた。 ベンチが内向きのときは、比較的均等に歩行軌跡がみられるが、外 向きのときはベンチの近辺を通っていないことが分かる。着座者は街 路にはみ出しておらず、歩行の邪魔となってはいないが、歩行者が ベンチの利用者の正面の近い位置を避けているものと考えられる。 夜間においても同様の傾向がみられた。また、ベンチとベンチの間 を通り抜ける人は、どちらのパターンでもほぼ同じであった。

表 1 に、調查日の気象条件と、ベンチの利用者数を示している。 日曜日は平日に比べ、街路自体が混み合っており、家族連れなどの グループでの利用者の割合も高かった。表より、ベンチの利用人数 も、昼間・夕方・夜間合計で、内向きの日が 260 名、外向きの日 が348名と最も多い。また、日曜日には、このベンチ近くの路上に 屋台が出ている時間帯があり、それによっても利用者が増えたり、飲 食などの行為が増えているものと思われた。そこで以降の分析では、 利用状況が特殊な休日のデータを外し、平日 3 日間の結果を扱うこ ととした。調査した平日には、近隣で集客に寄与するイベントなどは 行なわれていなかった。

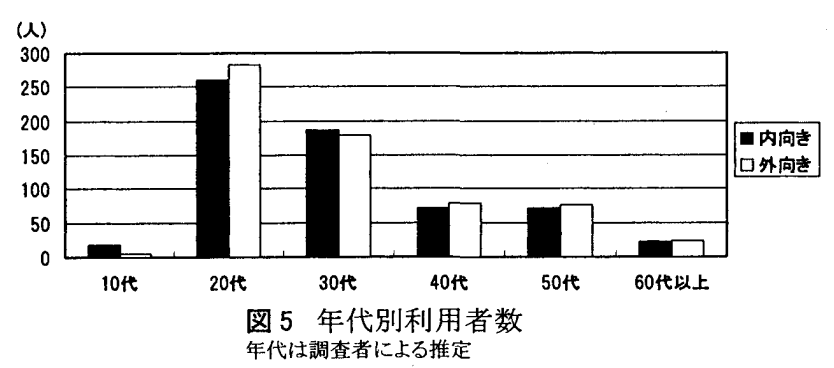

図5に利用者の年代を、表 2 に性別やグループの属性を示す。年 代や性別は調査者2名によって推定したものである。利用者は、20 代と30代が圧倒的に多く、40代以上は少ない。女性の利用者は男

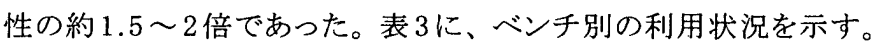
利用者数は、内向きの場合が計631名、外向きの場合が計646名 で、ほぼ同じである。ただし、男性は内向きより外向きの方が 35 名 多いのに対して、女性は内向きの方が 17 名多く、性別によって利 用しやすさに違いがあることが考えられる。

表 3 の左に、ベンチの利用時間率（調査時間中に、ベンチに一 人でも座っていた時間の割合)を、ベンチと時間帯別に示している。 昼間と夕方では、外向きの方が利用時間率がやや高い程度である が、夜間では全ベンチの平均值において、内向きが $35.9 \%$ 、外向 きが $63.0 \%$ と、27ポイントも差が生じている。夜間では歩行者の数 が少なく、ベンチの利用率自体は下がっているが、その中で、外向 きの場合の方が、利用しやすさが保たれているものと考えられる。そ の要因として、外向きの場合のアクセスのしやすさ、街路の照度が 低いため昼間ほど歩行者を気にしなくなること、夜間も店舗の内部照 明が点灯されていることでファサードが眺めやすくなること、などが考 えられる。ただし、内向きの方が外向きよりも気温がやや低く、その 差が影響したという可能性も否定できない。

表 3 から、ベンチによっても利用時間率に違いがあることが分か る。内向きではNo.3の利用時間率が最も高く、昼間では約 $85.6 \%$ 、 夜間では約 $55.6 \%$ であった。これは、対面にベンチがないことが主 な要因ではないかと考えられる。一方、外向きの場合には、全時間 を通して利用時間率が他より卓越するベンチはみられなかった。

図6に、滞在時間別の利用者数を示している。15分未満の滞在 がどちらの条件も多く、15分以上の利用者は少なくなっている。ただ し、30 分以上長く利用する者もみられ、内向きで 44 名、外向きで 65 名みられた。また、外向きは内向きよりも、 5 分未満が 33 名、30

表 2 利用者の属性

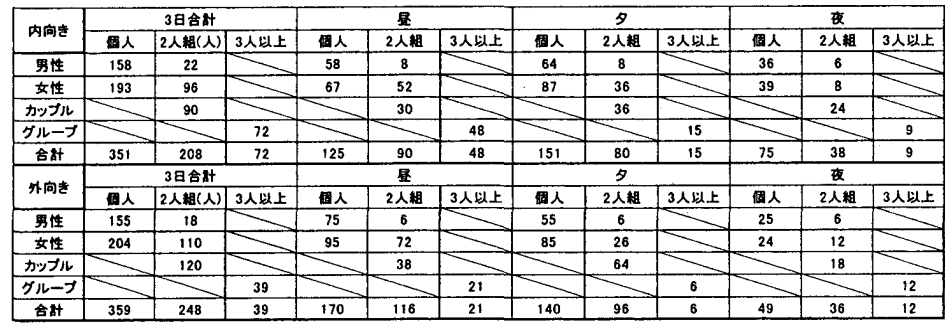

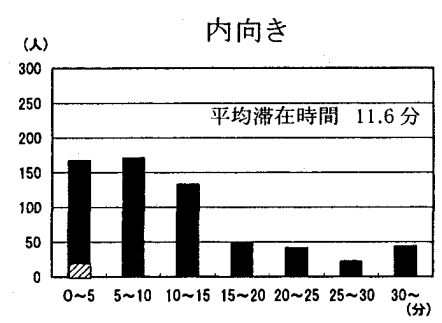

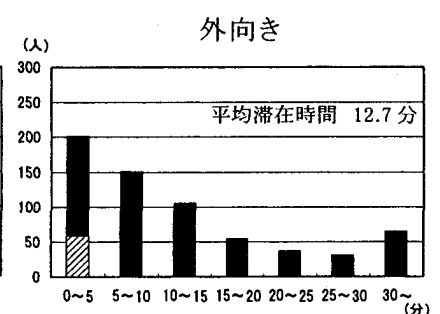

図 6 滞在時間別利用者数 斜線部は、 1 分末满の利用者を示寸

表 3 ベンチ別の時間帯別利用状況

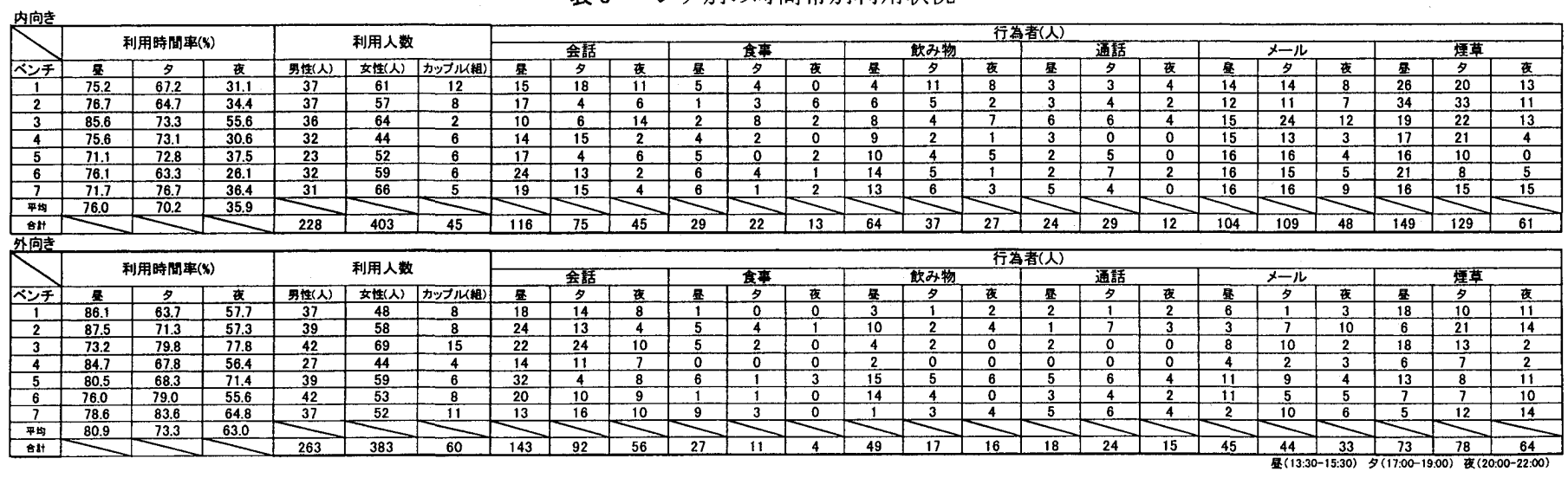


分以上が21名多く、それ以外の滞在時間帯では、内向きの方が多 い。外向きでは、座ったあと何もしなかったり、靴紐を結ぶだけだっ たりするなど、1分未満の非常に短時間の利用が 60 名と多くみられ た (内向きでは22名)。これは、街路からのアクセスのしやすさか ら、気軽に利用できたものと推測できる。

本観察調查では、内向きの場合と外向きの場合で、気温や日没時 間などの条件がやや異なっている。そこで、できる限り同一条件で の利用状況を比較するために、2007年6月に追加調査を行なった。 調査者は1名で、ベンチの利用者数と利用時間のみを調查した。結 果を表4に示す。表より、昼間と夕方では両条件で利用状況の差は 小さいが、夜間では外向きの条件が利用者数・利用時間率とも上 回っていることが分かる。これは、本観察実験の結果と類似してお り、この傾向は比較的安定しているものであるといえる。

\section{2) 行為内容}

内向き、外向き共に、ベンチでとられていた行為には、主なもの として「会話をする(会話)」「食事をする（食事）」「飲み物を飲む (飲み物)」「携帯電話で通話をする(通話)」「携帯電話を操作する (メール)」「煙草を吸う (煙草)」などがあった。表 3 にこれらの行 為者数をべンチごとに示し、図7に行為者数を性別と時間帯ごとに示 している。図8には、他の行為についての行為者数を、ベンチの 向きごとに示している。表 3 より、平日の 3 日間の合計において、6

表 4 追加調查の結果

\begin{tabular}{|c|c|c|c|c|c|c|c|c|c|c|}
\hline & \multirow[b]{2}{*}{ 調查日 } & \multirow[b]{2}{*}{ 天気 } & \multirow[b]{2}{*}{\begin{tabular}{|l} 
最高気 \\
温( $\left.{ }^{\circ} \mathrm{C}\right)$
\end{tabular}} & \multirow[b]{2}{*}{ 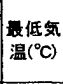 } & \multirow[b]{2}{*}{$\begin{array}{l}\text { 湿度 } \\
(\%)\end{array}$} & \multirow[b]{2}{*}{$\mid \begin{array}{c}\text { 日没時 } \\
\text { 刻 }\end{array}$} & \multicolumn{4}{|c|}{ 利用人数(上)、利用時間率(下) } \\
\hline & & & & & & & $\begin{array}{c}\text { 13:30- } \\
\text { 15:30 }\end{array}$ & $\begin{array}{c}\text { 夕17.00- } \\
19: 00\end{array}$ & $\begin{array}{c}\text { 夜20.00- } \\
22.00\end{array}$ & \\
\hline \multirow{2}{*}{ 内向气 } & \multirow{2}{*}{$\begin{array}{c}2007.6 .12 \\
\text { (火) }\end{array}$} & \multirow{2}{*}{ 睛九 } & \multirow{2}{*}{29} & \multirow{2}{*}{19} & \multirow{2}{*}{51} & \multirow{2}{*}{ 18:57 } & $91 \lambda$ & 77人 & $37 \lambda$ & 合埻 205人 \\
\hline & & & & & & & 76,78 & $75.8 \%$ & $39.6 \mathrm{x}$ & 平均 $64.0 \%$ \\
\hline \multirow{2}{*}{ 外向き } & \multirow{2}{*}{$\begin{array}{c}2007.6 .13 \\
\text { (水) }\end{array}$} & \multirow{2}{*}{ 睹れ } & \multirow{2}{*}{27} & & \multirow{2}{*}{57} & \multirow{2}{*}{$18: 57$} & 89 人 & 85人 & 59人 & 合計 233人 \\
\hline & & & & & & & $80.3 \%$ & $79.9 \%$ & 67.36 & 平均 $75.8 \%$ \\
\hline
\end{tabular}

内向き

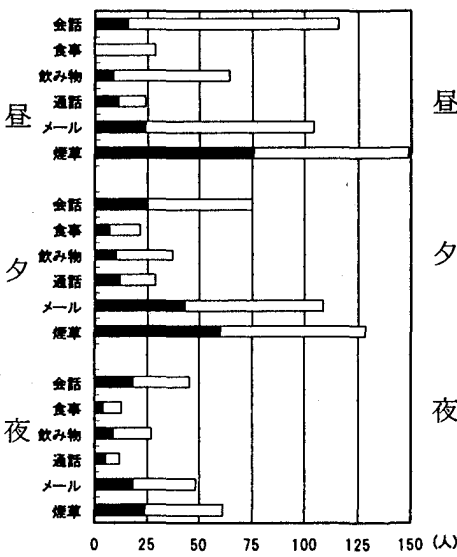

外向き

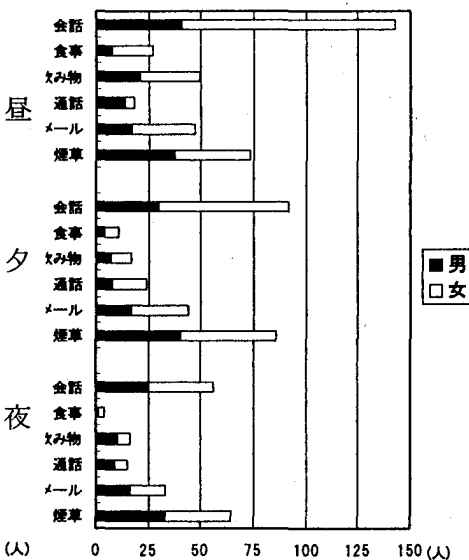

図 7 時間別・性別の主要行為者数

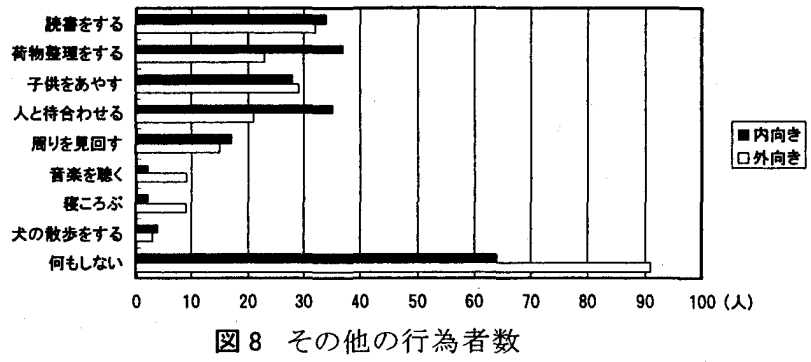

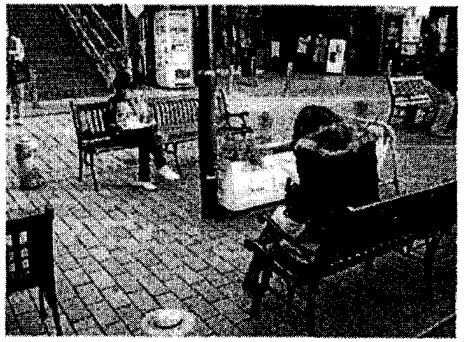

type A

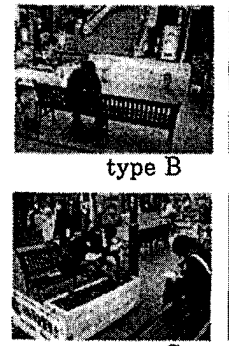

type C 図 10 実験風景(アンケート回答時)
つの行為の中で「会話」のみ、内向き (236名) より外向き (291名) の方が多くみられた。その他の行為はすべて内向きの方が上回って おり、「食事」は内向きと外向きの合計数がそれぞれ64名と 42 名、 「飲み物」は128名と82名、「通話」は65名と57名、「メール」は 261 名と 122 名、「煙草」は339名と 215 名である。「メール」と「煙 草」に関しては合計で 100 名以上の差が生じている。街路に面した 外向きの配置には、歩行者などからの視線を受けやすいため、「会 話」以外の行為をやりづらく感じているのではないかと推測できる。 同じ携帯電話の操作でも、「通話」では向きによる大きな差がないの に対して、「メール」では差が開いているのが特徴的である。

行為と時間帯については、ベンチの利用者数にほぼ比例し、全体 的に、昼間、夕方、夜間の順に行為者数は少なくなっている。ただ し、「通話」と「メール」に関しては、昼間と夕方がほぼ同じか、夕 方の行為者数が多いという特徵がある。

ベンチ別にみると、No.1〜No.3で「煙草」が多くみられている。こ の理由は灰皿との距離が近いためであると思われる。No.5のベンチ だけは、内向きよりも外向きの方が、「食事」「飲み物」「煙草」の 行為が多く行われている。外向きのときのこのベンチの前は、屋外 の幅広い階段があって大きく開けている。視線が抜けて開放的なこと が、それらの行為のしやすさに関連しているものと推測される。また この状況は、内向きのときのNo.3とも類似しており、このベンチの 利用時間率の高さとも関連していると考えられる。

\section{3. ベンチの配置による行為のしやすさの評価実験 3.1 実験概要}

観察調査から、ベンチの向きによって、利用者の頻度や生じやす い行為のタイプに違いがあることが分かった。そしてその原因として、
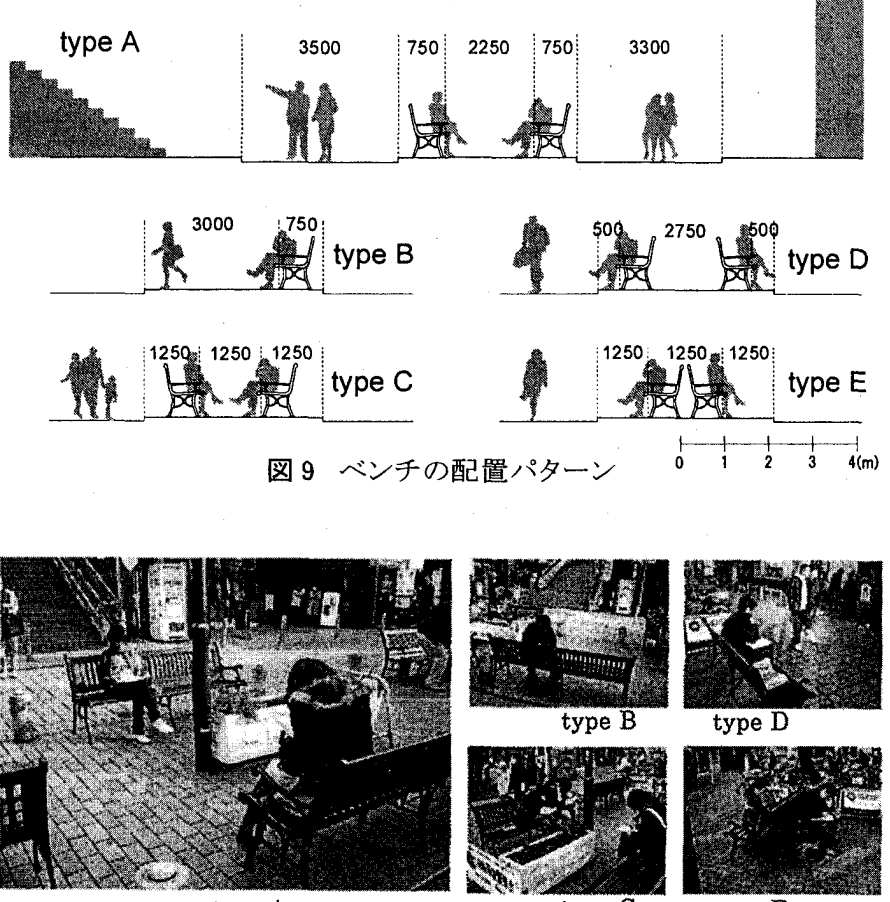

type $\mathrm{E}$ 

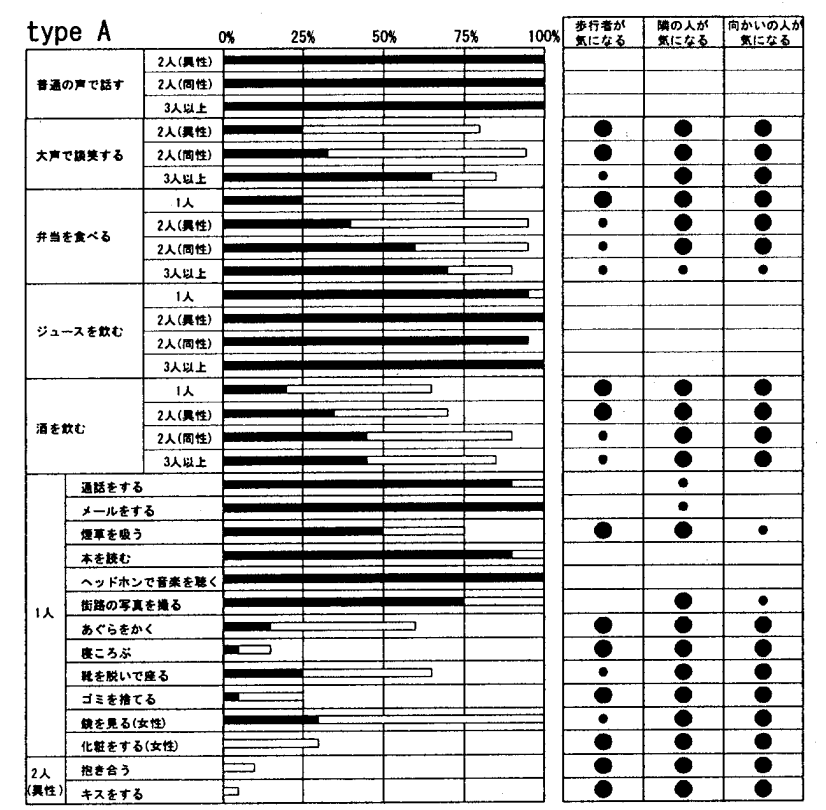

歩行者や他の着座者との向きや距離が関係していることが考えられ た。そこで、ベンチの配置による着座時の行為のしやすさと、それ に関わる歩行者などからの影響を把握するため、被験者による評価 実験を行うこととした。

ベンチの配置の種類は、街路に対する向きとベンチ同士の距離を 変数として、図 9 と以下に示す 5 種類 (type A〜 type E) に設定し た。

-type A (内向き) 前面のベンチとの距離 (座面先端同士) $: 2.25 \mathrm{~m}$ •type B (内向き） type Aの配置で、前面のベンチ無し -type C (内向き) 前面のベンチとの距離: $1.25 \mathrm{~m}$
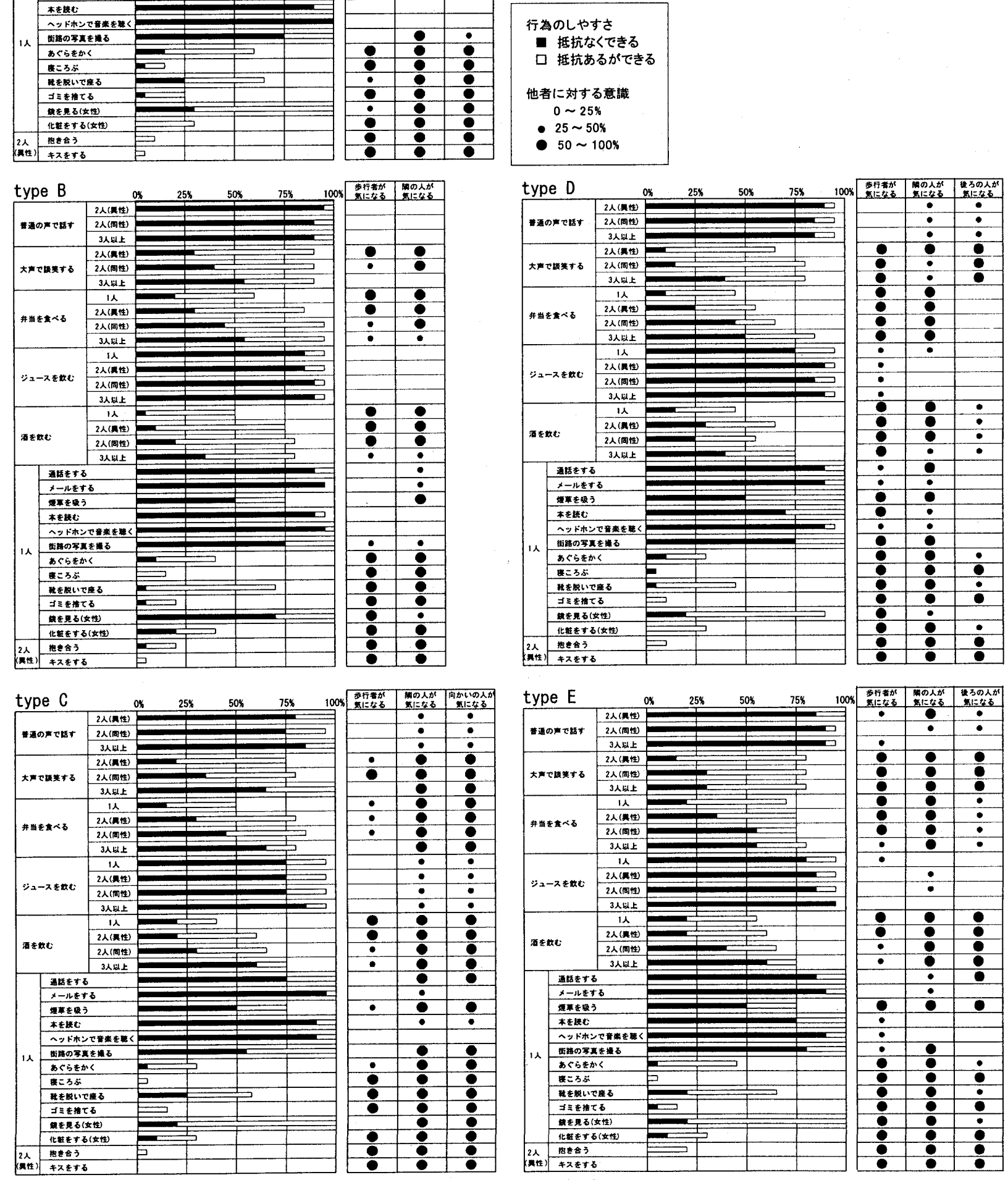

図 11 行為のしやすさの評価結果 
•type D （外向き） 背面のベンチとの距離: $2.75 \mathrm{~m}$

·type E (外向き) 背面のベンチとの距離 : $1.25 \mathrm{~m}$ type Aは、現状の九品仏川緑道のベンチの配置であり、先の調查 の「内向き」の場合である。 type D は先の調查の「外向き」であ る。

評価項目は、調查時に観察された行為と、ベンチの配置に左右さ れると考えられた行為とした。この街路でほとんどとられることのない行 為であっても、抵抗の強さを把握するためにあえて加えたものもある。 行為は 19 種類で、その内 5 種類の行為は、「一人で行なう」「異性 (恋人) と 2 人で行なう」「同性 (の友人) と 2 人で行なう」「 3 人以上 の友人で行なう」など、行為をする人数設定も変えている。各々の行 為について「抵抗なくできる」「抵抗があるできる」「できない」の 3 段階で評価するものとした。さらに、その行為をする際の周囲の人 の視線や存在について、「気になる」「気にならない」の2段階で評 価するものとした。

実験は、2005年11月の平日の $13: 30 〜 15: 30$ に行なった。被 験者は19〜22歳の大学生 20 名（男性 10名、女性 10名）とした。 各々の条件で、正面や背面に他の被験者がいる状態で評価するも のとした注2)。他のベンチに着座するもの同士は面識がない。

\section{2 実験結果と考察}

実験結果を図 11 に示す。内向きのtype A は、外向きのtype D と比べて全体的に行為のしやすさが上回っており、観察調查の結果 とも一致している。type Dでは、「弁当を食べる」「酒を飲む」といっ た飲食行為が、「抵抗なくできる」と「抵抗あるができる」の合計が $50 \%$ 前後であり、5つの条件の中で最も低い。そして、それらの行 為をするのに歩行者が気になる、という割合が $50 \%$ 以上となってい る。type Aでは、飲食行為に対して歩行者が気になる、という割合 は $50 \%$ 未満となることが多いものの、type Dより向かいに座る人 (type Dでは後ろに座る人) が気になるという割合が高くなっている。 内向きで、向き合う距離の異なるtype A とtype Cを比較すると、 距離の離れたAの方が、全体的にやや行為がしやすいと評価されて いる。他者への意識では、歩行者へはCよりAの方が気になるとし ており、隣の（ベンチの）人と向かいの（ベンチの）人へは、Aよ りCの方が気になるとしている。街路とベンチとの距離、ベンチ同士 の向き合う距離が反映された結果となっている。

内向きで、向き合うベンチのあるtype A とないtype Bでは、行為 のしやすさの違いはあまりみられない。その中で、一人で「弁当を 食べる」「酒を飲む」「あぐらをかく」行為が、BよりもAの方がしや すいと評価されている。2名以上での行為では、差はほとんどない。 前方が開けたBでは、プライベートな行為をするのに正面の歩行者 が気になることが影響しているものと思われる。また、女性被験者の 「鏡を見る」「化粧をする」行為は、Bの方がしやすいと評価されてい る。Aでは、向かいに座る人が気になることが影響しているものと考 えられる。

外向きで街路との距離の異なるtype D とtype Eを比較する。「大 声で談笑する」弁当を食べる」行為は、街路と離れているEの方が しやすいと評価されている。その他の行為では、あまり差はみられな い。EよりもDの方が、歩行者が気になる割合が高いが、後ろに座 る人が気になる割合には大きな差はみられなかった。

行為をする際の人数では、どの行為に関しても、1人よりも 2 人以
上でする方が、「抵抗なくできる」と答えた人が多い。しかし、2人 （異性）での「抱き合う「「スをする」行為は、ほとんどが「できない」 としており、本街路のような店舗前面の着座空間では、ベンチの配 置を多少変えたとしても、依然として抵抗の強い行為であるといえる。 同様に、「寝ころぶ」「ゴミを捨てる」「化粧をする」行為もすべての 配置において、「できる」人が少数である。観察調査で実際にみら れた行為であるが、ベンチの配置よりも個人の性格や行動パターン に強く依存するものだと考えられる。その他、「ジュースを飲む」「通 話をする」「メールをする」「本を読む」「ヘッドホンで音楽を聴く」行 為は、どのタイプもほとんどの被験者が「抵抗なくできる」としている。

以上の評価結果から、内向きのベンチの配置は外向きよりも全体 的に着座時の行為のしやすさが上回っていることが確認された。また 内向きの場合には、前後のベンチの距離が長い方が、行為はやや しやすくなることが分かった。しかし外向きの場合は、前後のベンチ 同士の距離（あるいは街路とベンチの距離）の影響は小さいことが 分かった。

\section{4. 結論}

本研究では、歩行者中心の街路の中にある着座空間において、 ベンチの配置の仕方と着座者の行為のしやすさとの関係を調べるた め、一般利用者の行動観察調査と被験者による評価実験を行なっ た。得られた主な結果を以下にまとめる。

ベンチの利用者 (着座者) 数は、外向き(街路向き) と内向き(街 路に背を向けた配置)で、昼間と夕方はほぼ同じであったが、夜間 は外向きの方が多かった。また、1分未満の短時間の利用者は外向 きの方が多かった。これは、利用率が下がる時間帯や少しの間だけ 座りたい場合など、着座に対する強い意思がない場合に、街路から ベンチへのアクセスのしやすさが着座行為を促すことになっているの ではないかと考えられた。さらに、男性は内向きより外向きの方が利 用者がやや多いのに対して、女性は内向きの方が多く、性別によっ て利用しやすい向きに違いがあることも考えられた。

飲食行為や携帯電話の操作など、着座しながらなされる行為は、 外向きよりも内向きの場合の方が多かった。また被験者実験によっ て、それらの行為をすることに対して、内向きの場合は対面に座る 人が、外向きの場合は歩行者が気になると評価された。これらの結 果から、他の着座者よりも歩行者の方が、行為のしやすさに強い対 人的な影響を与えていることが考えられた。

被験者実験から、内向きの場合には、前後のベンチの距離が長 い方が、飲食などの行為がややしやすいと評価された。一方、外向 きの場合は、前後のベンチ同士の距離の行為のしやすさに与える影 響は小さかった。

以上のように、商業店舗が並ぶ歩行者中心の街路にある着座空間 では、様々な種類の行為がなされ、そこに配置されたベンチの向き や位置によって、利用しやすさや着座時の行為のしやすさに影響を 与えることが分かった。これらの知見は、街路にふさわしい特定の 行為を促したり、逆にふさわしくない行為を防いだりするような、屋外 での着座空間のデザインに需与するものと考えられる。今後の課題 としては、気温や日照、湿度などの気象条件による着座行為の影響 を検討すること、ベンチの周辺の歩行者や建物の影響を検討するこ と、利用者の年齢層による行為のとり方の違いを検討することが挙げ 
られる。

\section{謝辞}

本研究は、武藏工業大学建築学科卒論生の白井裕介氏と協同で 行いました。記して謝意を表します。

注 1）調査時間が過ぎても着座者がいる場合、それらの人々がベンチを離れ るまでの時間は測っている。

注2）行為を一人でするという設定のときは、被験者はベンチに一人で着座し、 2 人以上の設定のときは 2 人で着座して評価するようにした。「煙草を吸う」 行為は喫煙者のみが評価し、「鏡を見る」と「化粧をする」行為は女性のみ が評価した。また、被験者のうち 12 名は A,B,C,D，Eの順番で評洒し、8 名は $\mathrm{E}, \mathrm{D}, \mathrm{C}, \mathrm{B}, \mathrm{A}$ の順番で評価した。

\section{参考文献}

1）R. Sommer（䅖山貞登 訳):人間の空間 -デザインの行動的研究、鹿島出 版会、1972
2）小松尚、柳沢忠、加藤彰一、谷口元：病院待合座席配置の利用者に対 する有効性に関する研究、日本建築学会計画系論文報告集、No.449、 pp.39-46、1993.7

3）大島秀明、天野克也、浅沼由紀、谷口汎邦：高齢者の外出行動と座りス ペース利用に関する研究 品川区の場合、日本建築学会計画系論文集、 No.563、pp.171-177、2003.1

4）大島秀明、天野克也、谷口汎邦：商店街来街者の座りスペース利用に関 する研究一宩鴨地蔵通り商店街の場合一、日本建築学会計画系論文集、 No.610、pp.41-46、2006.12

5）吉田圭一、上野淳、登張絵夢：モール状都市オープンスペースにおける 線状着座滞在とその相互距離に関する考察 新宿サザンテラスにおけるケー ススタディ、日本建築学会計画系論文集、No.574、pp.47-54、2003.12

6）堀口沙記子、杉田早苗、土肥真人 : 着座行為と着座者の選好からみた街 路空間における着座行為に関する研究、日本都市計画学会術研究論文集、 No.36、pp.763-768、2001.10

7）森一彦、西脇智子：池のある公園におけるべンチの使われ方に関する研 究 着座向きと行為内容の関連、日本建築学会計画系論文集、No.585、 pp.71-77、2004.11

（2007年 3 月 7 日原稿受理，2007年 8 月10日探用決定） 